\title{
Essay
}

\section{Questioning COVID-19 Pre-packaged Solidarity Initiatives in the Dutch Urban Spaces}

\author{
Marija Sniečkutè \\ University of Amsterdam \\ Elisa Fiore \\ Radboud University Nijmegen
}

The COVID-19 pandemic and subsequent lockdown has drastically transformed the urban topography and rhythms of the Dutch cities, both in the streets and when "seen from the window" (Lefebvre 1992/2004, 27). Windows and balconies, the liminal spaces where the private and public meet and depart, have become sites not only to "gaze from" but also to "gaze at". Teddy bears, children's drawings and letters, white T-shirts with red hearts hanging on/from the windows, as well as flags fluttering from balconies, all contributed to transforming this retracted border of cityness into a political space of communication. Similarly, the windows of commercial spaces have turned into message boards of unity and solidarity, with posters at once inviting customers to support local businesses and boosting feelings of locality. Despite their situatedness, most of these practices have a transnational character, creating a symbolic pandemic of its own. These symbols also share another characteristic - they convey messages of empathy, solidarity, and support. However, we wonder, to what extent are these initiatives a veritable token of solidarity? And how can we understand such solidarity initiatives in the Dutch urban context during this time of pandemic? In this essay, we try to provide a tentative answer to these questions by zooming in on two solidarity initiatives that emerged in response to the current COVID-19 pandemic: the red flag "With Each Other, For Each Other!" ("Met Elkaar, Voor Elkaar!") widely exhibited in residential areas across Amsterdam and beyond; and the commercial initiative Javakaart in support of local businesses in the Indische Buurt, a rapidly gentrifying neighbourhood in the East of Amsterdam. 

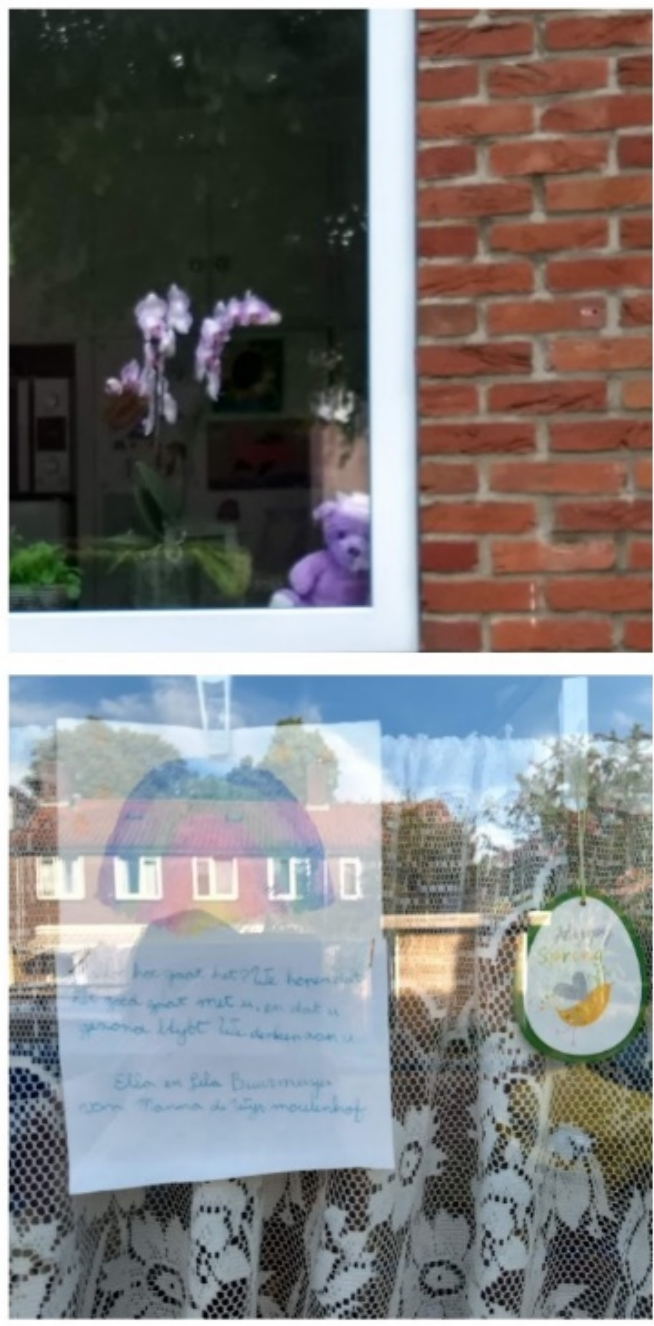

Figure 1: April - May 2020, Amsterdam. Credit: M.Sniečkutè

\section{The Red Flag as a Solidarity Token? by Marija Sniečkutè}

With the lockdown, I began noticing more and more red flags in Amsterdam and other cities. I shortly touched upon this novel phenomenon in my commentary on trust in the GOVID-19 times (Sniečkutè and Gaižauskaite 2020), and I wanted to have a closer look at it. The flag "With Each Other, For Each Other!" is produced by "Dokkumer Vlaggen Centrale" (DVC), a Dutch company specializing in flags and commercial banners (DVC 2020a). DVC dates back to the $18^{\text {th }}$ century, with a turning point in 1936, when, following the engagement of Princess Juliana, it sold 35,000 small flags within four months. Today it is a proud family company presenting itself as the leader in the Dutch market and a large player in the European market, with an annual turnover of $€ 14,2$ million. According to the DVC general director, after the lockdown was implemented, their clients started asking DVC if 
there was a 'special flag for the corona crisis', but the company had nothing to offer (Hageman 2020). Then the company received a slogan - actually an idea of a member of 'Ladies' Circle 65 Bossche Parels' (Waldnet 2020) - and, after a successful pilot on social media, the flag was launched and immediately 'hundreds of orders were coming in' (Hageman 2020). The flag has both symbolic and economic uses. Symbolically, the company suggests two reasons for ordering the flag: "Show that you are proud of all the hard workers of our society", and "[Express] [t] he feeling of togetherness during the corona crisis" (DVC 2020b). Economically, the company donates $€ 2,50$ from every sold flag to the Red Cross. DVC representatives reiterated that the company was not making any profit by selling flags, and the full price $(€ 7,50$, incl. VAT) covered only production costs.
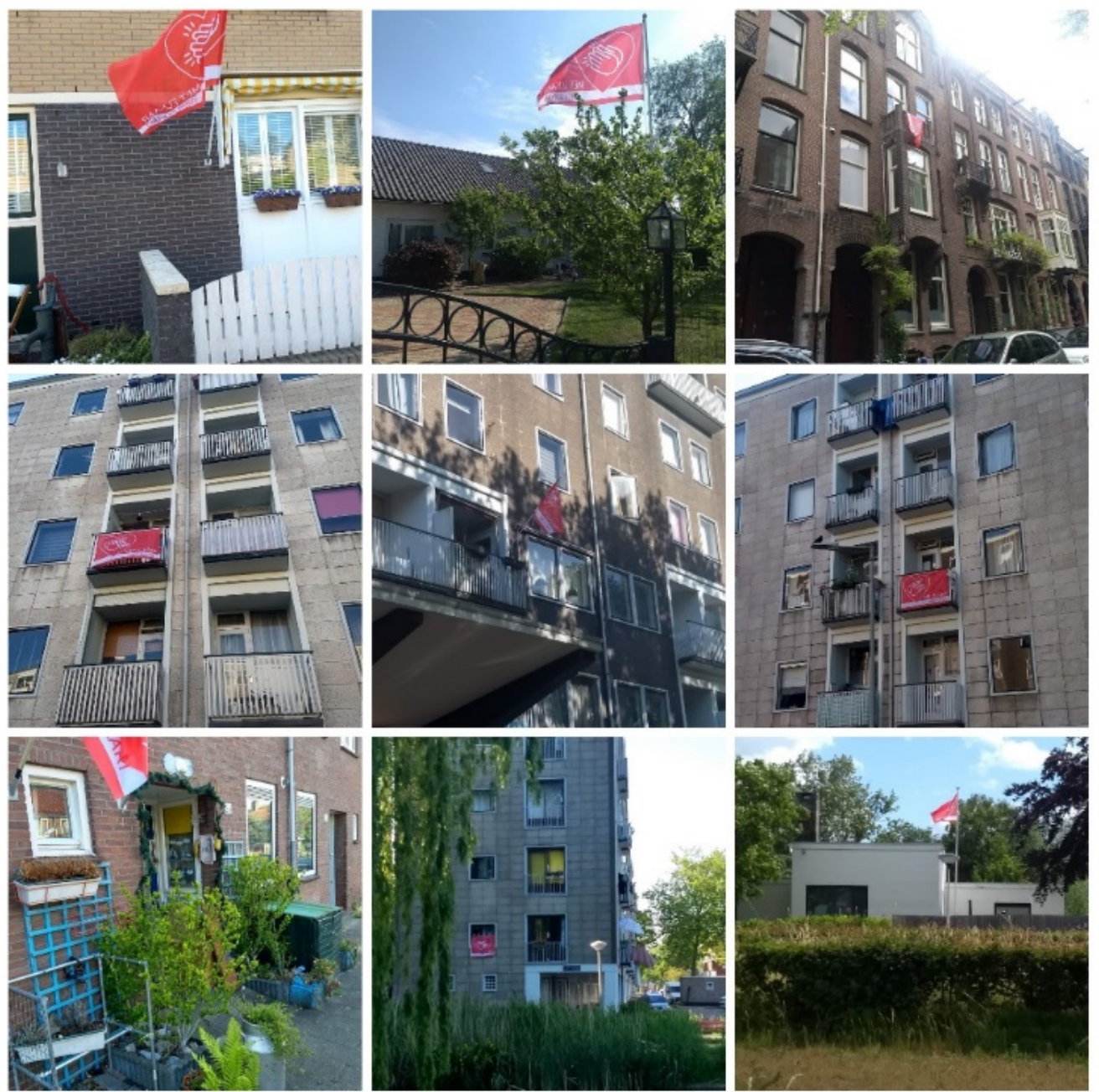

Figure 3 - 17 April - 6 June 2020, Amsterdam, Hoofdorp, Wormeer. Credit: M.Sniečkutè

Although the initial idea was to sell 10,000 flags, the campaign sold 25,000 flags in total. On April 3rd, in a Zoom-like conference mode, DVC handed in a €25,000 cheque to the Red Cross (DVC 2020b), and on the 25th of May (Waldnet 2020) 
the second cheque of $€ 12500$. At the end of June, it was still possible to buy the flag online, but with no further donations attached.

The symbols of clapping hands and a heart, the use of such slogans such as "With Each Other, For Each Other!" and charged metaphorical expressions such as "to put a heart under the belt" (een hart onder de riem te steken) (DVC 2020b), all tap into people's agitated feelings. While not denying the increased feelings of solidarity, it is hard not to notice the raw economics visible in the profiteering and branding practices. It is, indeed, difficult to trace the direct financial profit from selling the flags, since DVG representatives consistently deny it. However, companies can generate profit even from "delivery costs" (Leigh 2020), and DVC directly profits from sales now. Moreover, DVC introduced a whole new range of corona-related products, such as face masks (with the same brand of clapping hands), window stickers, preventive screens and dividers, vests and shirts, among others - branding from which it further benefits.

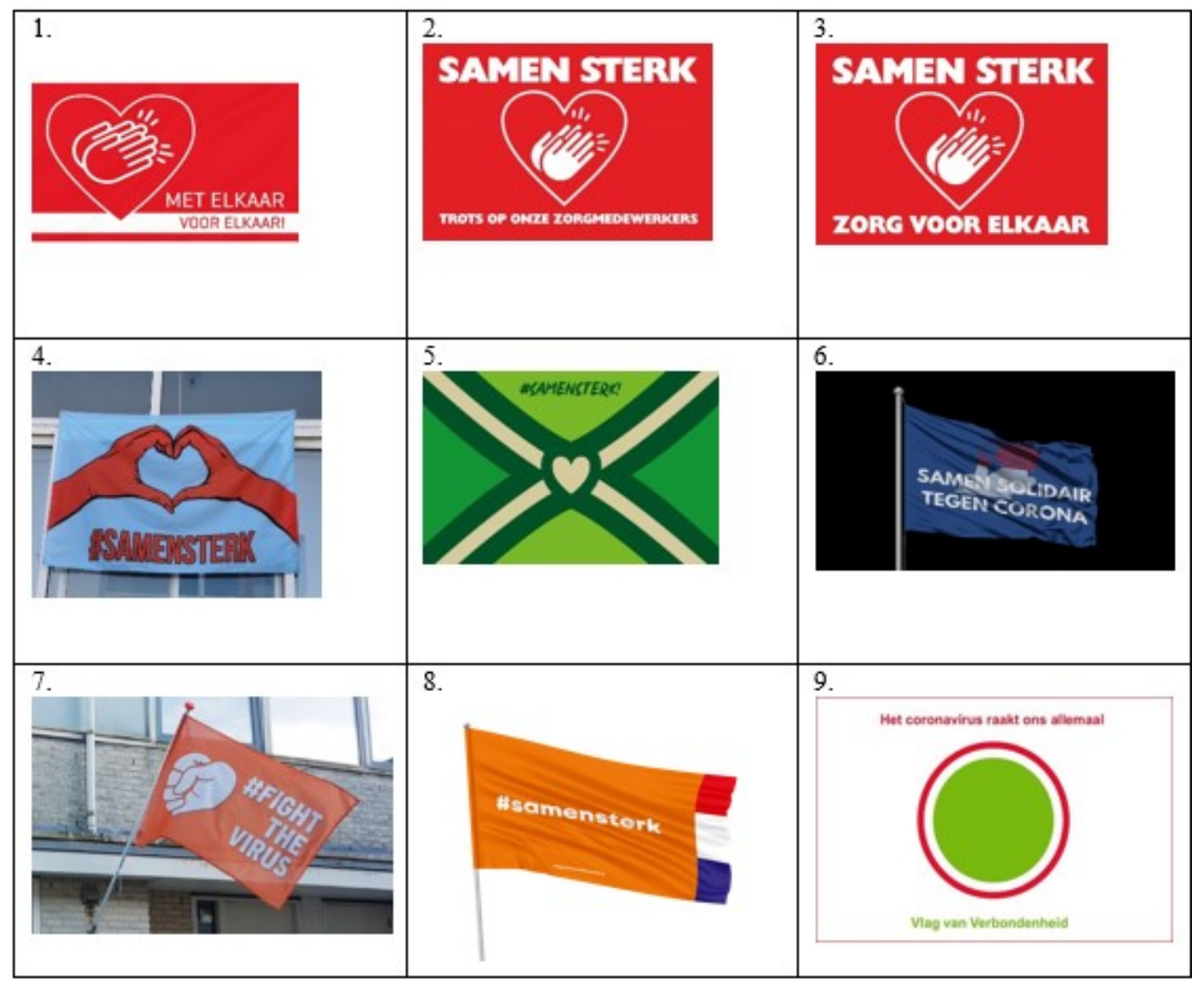

Figure 4 - (1) Dokkum Vlaggen Centrale (Dvc 2020b), $€ 7,5$ (incl. VAT), donation $€ 2,5$ per sold flag to Red Cross; (2) Drukidee (2020), $€ 11,95$, no donation; (3) Drukidee (2020), $€ 11,95$, no donation; (4) ProjectSamenSterk (2020), €9,5 (incl. VAT), donation for Doctors Without Borders; (5) Zwarte Cross (2020), free paper version, no donation; (6) Red Cross (2020)2; (7) Faber Vlaggen (2020), $€ 12,10$ (incl. VAT), $€$ 2,5 per sold flag to Covid-19 Solidarity Respons Fund; (8) Brand Specials, CCV Shop \& Tikkie Nederland (2020), $€ 15$ (incl. VAT), donation to Kansfonds; Designed by Zeus Hoendorp (Vorstermans 2020), sold on Vlaggenclub (2020), €23,95, no donation. 
The relationship between the solidarity flag and the logic of profit is even more striking when one zooms out to see the market bubbling with other fiercely competing flags, both nationally and locally. Some flags are almost identical copies of the DVC flag (see No. 2 and No. 3 in Figure 3), while the Red Cross had its own flag, (see No. 6 in Figure 3) which was available at least until the end of April (Rijssen-Holtens Nieuwsblad 2020). Most initiators are commercial companies dealing in flags, printing and marketing. It is noteworthy that there is a strong tendency to use national colours and geographical imagery in these flags. As one marketing bureau puts it: "What a beautiful new house-style the Netherlands is now developing. Everywhere you see \#togetherstrong coming back. <..> A new national style" (Contentplace.nl 2020).

But what about the people who erect these flags on their windowsills? Different reasons come into play - from relatives working in the healthcare sector to passing truck drivers seeing the flags; "there is so little that we can do from the sidelines. So, anything that could support the other, I would do with a pleasure" (UitgeestOnline.nl 2020). People's motivations are multi-layered revealing that the slogan "With Each Other! For Each Other!" is stretchy, and people imbue it primarily with personal and local meanings. What stands out in my own observations, is that there are "local infections" of these red flags, i.e., flags tend to hang in small communities, village-like urban units, particularly there where people already share the history of celebrating national days together and having BBQ's (UitgeestOnlline.nl 2020). My observations of "red communities" coupled with the results of local elections (Gemeente Amsterdam 2018b) raise also an interesting question of whether there is a correlation between (performative) civic solidarity and leftwing political views.

There is more to the "solidarity flag" in the COVID-19 pandemic times than meets the eye. The solidarity flag shows not only how the symbolic and the economic logic go hand-in-hand, but also reveals the workings of the neoliberal logic. As Ieven and Overwijk (2020) observe, neoliberalism has always been primarily a "politics of containment". Therefore, any real democratic politics based on collective solidarity and equality is being contained through careful dosage and channeling. Even Friedrich Hayek, one of the main progenitors of neoliberalism, openly argued that politics must be dethroned; or as Ieven and Overwijk put it, upon this view, "like the coronavirus, democratic politics is a threat to the primacy of the market" (Ieven and Overwijk 2020). Pre-packaged solidarity flags, geared with marketing and profit interests on the production side, exemplify how market bounces back in the pandemic times to reclaim its superiority over politics. And it does so with the symbol of clapping hands, which camouflages, or even silences a more radical criticism of politics pertaining to the healthcare sector, e.g., bureaucracy and budgetary cuts. More than that, neoliberalism aligns with "hypernationalism": even though the red flag claims solidarity with the representatives of "vital professions", those vulnerable and in need, and, simply, "with each other", it becomes articulated as the "national", i.e., Dutch flag. In this way, the initial 
transnational impulses of solidarity are rendered into national identifications, something that can make us question these solidarity initiatives further.

\section{Support SOME Locals: Javakaart and the Indische Buurt by Elisa Fiore}

Over the past four years, I have conducted research on gentrification in a formerly immigrant neighbourhood located in the East of Amsterdam called Indische Buurt. In the course of barely ten years, the neighbourhood went from being considered the least appreciated neighbourhood in the whole city (Redactie Het Parool 2010) and a forlorn district at the mercy of immigrant criminal gangs (Kok 2014) to being elected one of the 'hippest and coolest hotspots of the city' (de Vries and van der Pol 2015). The Javastraat, the shopping artery of the neighbourhood, has become the symbol of the area's transformation. Once home to many small Turkish- and Moroccan-owned greengrocers and butchers, the Javastraat is now replete with high-end clothing stores, hip cafés, and expensive restaurants (Sakizlioglu and Lees 2019, van Eck, Hagemans, and Rath 2020). As I have extensively analysed elsewhere (Fiore and Plate forthcoming), this striking change was the result of two successive waves of state-led regeneration and a neighbourhood branding operation explicitly targeting local immigrant entrepreneurs with an aim to market the Javastraat and surroundings as 'just another piece of authentic, cosmopolitan Amsterdam' (Gemeente Amsterdam 2018, 3). Through a parallel process of spatial rezoning and renaming, and the creation of an aestheticized space for diversity consumption, city authorities succeeded in creating a recognisable spatial brand that marketed the Indische Buurt as the living embodiment of multicultural Amsterdam.

However, the COVID-19 pandemic and the governmental ban on the catering and restaurant industry threatened to wipe out all the changes and improvements the city government had achieved through years of strenuous urban renewal operations and massive financial investments. With a renovated economy heavily reliant on catering activities and high-priced boutiques, the Javastraat revealed itself as particularly vulnerable to the economic effects of the COVID-19 outbreak. It is in this crisis context that a brand-new initiative called Javakaart was launched by the organisation of local entrepreneurs in collaboration with the city government, with an aim to support the renovated local economy of the Indische Buurt. I found out about it at the end of April 2020, when I visited the Javastraat for the first time since the start of the lockdown in The Netherlands. It was a sunny Sunday, and the sidewalks were busy with people. Had it not been for the closed terraces and restaurants and the orderly lines of people waiting outside of the local groceries, one would think that the Javastraat had been spared by COVID-19 altogether. The only visible signs that reminded passers-by of the pandemic were the bright-red Favakaart posters hanging on each and every shop window on the street summoning people to ' $[\mathrm{h}]$ old $1.5 \mathrm{~m}$ distance! Together we can make sure that local shops can stay open' (see Fig. 4 and 5). The posters explicitly connected Javakaart to the national campaign Support Your Locals (SYL), launched in the wake 
of the catering ban by two Amsterdam-based entrepreneurs to support small local food producers and help them survive the crisis. The rationale behind the campaign was to create "short supply chains" between consumers and food producers so as to encourage people to shop locally rather than hoard products in the big supermarkets.

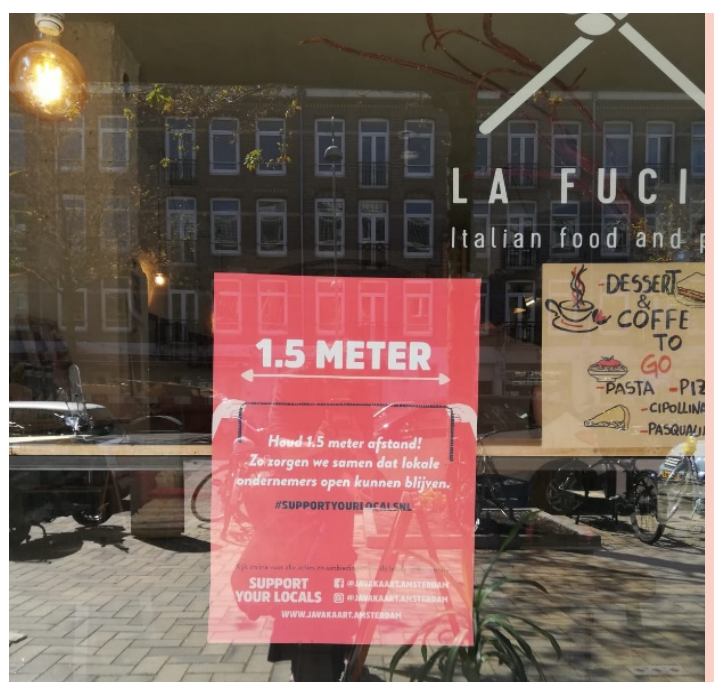

Figure 4 - Poster on one of the local restaurant windows. Credit: E. Fiore.

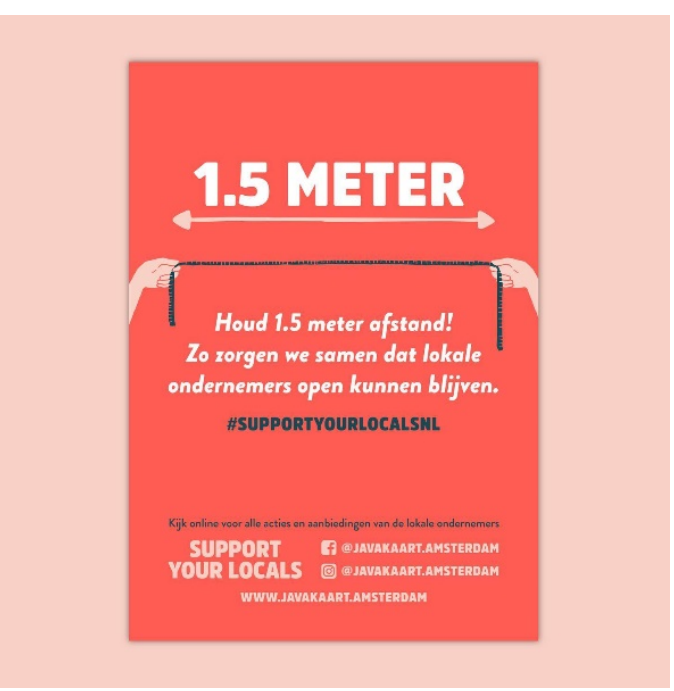

Figure 5 - Safety distance poster design. Source: Javakaart Facebook page.

While explicitly situated within the framework of the SYL campaign, the nineteen offers and deals featured on the Favakaart website have very little to do with local food producers and sellers. All that customers can buy there are gift vouchers from some of the post-regeneration restaurants and bars, and three themed product packs also from post-regeneration businesses - a rum-and-cola survival pack, a specialty coffee and tea pack, and an "exotic" products foodie bag. I found myself wondering why, despite distributing posters to all shops in the Javastraat, the initiative did not feature any of the Turkish and Moroccan groceries, bakeries, butcheries, and patisseries in the area, ${ }^{3}$ especially given their explicit connection with the SYL campaign.

I approached the creator of the Favakaart initiative - who incidentally serves also as street manager ${ }^{4}$ for the organisation of local entrepreneurs - to discuss with him the above discrepancies. He explained that even though Javakaart was launched in the aftermath of the COVID-19 pandemic, the idea had been brewing for a while already. 'Gavakaart has been initiated by the organisation of local entrepreneurs, and soon it will be widely advertised so that also people living outside of the neighbourhood can see how cool it is to shop [on the Javastraat].' This is why the initiative is broader in scope than SYL and offers much more than food. 'We wanted to represent the interests of all the shop owners in the area. We also have 
clothing stores or luxury retail stores who need support in these difficult times.' Moreover, he added, immigrant-owned stores 'have already been greatly helped in the past, $[\ldots]$ but at some point, there was no more budget for it, so that was not paid anymore [he refers to the aforementioned state-led branding operation].' Excluded from any form of institutional support, immigrant entrepreneurs are only featured on the Favakaart website as a series of charcoal portraits and life stories adding couleur locale to the whole initiative.

Although no definitive conclusion can be drawn about favakaart, the above seems to indicate a striking continuity between this initiative and the exclusionary regeneration strategies deployed by city authorities throughout the years. Local ethnic diversity in the area continues to be valued by institutional and other regeneration stakeholders primarily as a visual signifier of multiculturalism, accruing the value of place but without extending the same revaluation to immigrant entrepreneurs and residents themselves (Summers 2019). In this context, as in the case of the red flags, the red Favakaart posters have both a symbolic and economic use. Symbolically, they were functional to conjure the multicultural urban village imaginary that the renovated Indische Buurt is said to embody, i.e. that of a local community united across social and ethnic differences. Economically, they advanced the institutional project for the economic restructuring of the Indische Buurt as a white, middle-class space of leisure and consumption, thus widening the existing racial and class fault lines intrinsic in the regeneration process since its conception.

\section{Conclusion}

The above cases shed light on the inextricability of the symbolic and economic logic of profit at work in two COVID-related solidarity initiatives in Amsterdam and beyond at the beginning of the pandemic. By starting from the visual manifestation of these campaigns in urban space, we were able to account for the fieldspecificity of these solidarity practices and thereby to critically highlight, on the one hand, branding and profiteering practices imbued with commercial interests, and, on the other hand, the reinforcement of exclusionary practices of local identity and community engagement. While different in their nature, both initiatives similarly shed light on the pervasive neoliberal logic intrinsic in initiatives adopting the language of solidarity as a way to pursue their own self-interest. In the case of the red flags, neoliberalism logic plays out by activation of market interests, which - with all the available marketing strategies and capital - forcibly permeate the openings of political spaces fertile of democratic potential based on solidarity and equality. Neoliberalism, as a form of politics of containment, channels the civic solidarity impulses into performative and visual images of euphoria, which camouflages the more structural ailments of social institutions (e.g., healthcare) and silences their radical critique. Such logic of neoliberalism activates the luring tenets of nationalism ideology, thereby further undermining the power of transnational civic solidarity. The Favakaart project, instead, sheds light on the opportunistic appropriation of a nationwide solidarity initiative to advance exclusionary institutional and commercial interests on a local level. By promoting and support- 
ing a consumption culture that predominantly engages white, wealthier bodies, the initiative reveals the intricacies of race, neoliberal urbanism, and Dutch racial nationalism. The products advertised on the Favakaart website and the shops that sell them function as status-conferring objects and places (Boterman 2020) connected to a specific lifestyle and behaviour that is not just middle-class, but also forms a quintessential part of normative ideas about Dutchness as hip, wealthy, healthy, young, and - most importantly - Christian and ethnically white (see e.g. de Leeuw \& van Wiechelen 2014). Rather than a veritable solidarity initiative, then, Javakaart appears to serve as just another neighbourhood branding operation pushing further the racialised and classed ideology of regeneration that has shaped the transformation of the Indische Buurt over the past ten years, and that has led to the gradual destabilisation and marginalisation of local immigrant entrepreneurship and livelihood. This confirms what was found by Masuda and Bookman (2018) on the entrepreneurial phenomenon of neighbourhood branding as a primary enabler of urban gentrification and dispossession. Ultimately, with a critical finger on the solidarity flags and posters in times of COVID-19, one feels the pulse of a long-living tandem between neoliberalism and nationalism. The next question is: how should solidarity be liberated and democratic politics revived?

\section{References}

Boterman, Willem R. 2020. Carrying Class and Gender: Cargo Bikes as Symbolic Markers of Egalitarian Gender Role of Urban Middle Classes in Dutch Inner Cities. Social \& Cultural Geography. 21(2), 245-264.

Brand Specials, CGV Shop and Tikkie Nederland. 2020. Homepage. Accessed June 25. https://vlagvoornederland.nl/.

Contentplace.nl. 2020. "\#Samensterk. Samen We Vertellen Jouw Verhaal.” Accessed 25 June. https://contentplace.nl/2020/04/samensterk-nieuwe-nationale-huisstijl/.

de Vries, Anne, and Tjarko van der Pol. 2015. "Indische Buurt." Uitkrant, 36-37. de Leeuw, Marc, and Sonja van Wiechelen. 2014. "Institutionalising the Muslim Other: 'Naar Nederland' and the Violence of Culturalism.” In: Philomena Essed (Ed.), Dutch Racism (pp. 337-354). Amsterdam and New York: Rodopi Editions.

Drukidee. 2020. "Vlag Samen Sterk, Formaat 70x100cm.". Accessed June 25. https://www.drukidee.com/product/1429799/vlag-samen-sterk-formaat70x100-cm-vlaggen-kunnen-niet-afgehaald-worden-alleen-nog-maarverzenden-rechtstreeks-vanaf-de-fabriek.

DVC. 2020a. Homepage. Accessed June 25. https://www.dvc.nl.

DVC. 2020b. "Vlag 'Met Elkaar, Voor Elkaar!” Filmed 23 March 2020. Accessed June 25. https://www.dvc.nl/met-elkaar-voor-elkaar.

Faber Vlaggen. 2020. Homepage. Accessed 25 June. https://www.fabervlaggen.nl/.

Fiore, Elisa, and Liedeke Plate. forthcoming. "Food and White Multiculturalism: Racial Aesthetics of Commercial Gentrification in Amsterdam's Javastraat." Space and Culture. 
Gemeente Amsterdam. 2018a. Factsheet Experimenten Stad in Balance: Foodstreet Amsterdam/Javakwartier. Amsterdam.

Gemeente Amsterdam. 2018b. "Verkiezingen Gemeenterad 2018 - Uitslagen Per Stemlocatie." Accessed 25 June. https://maps.amsterdam.nl/gemeenteraad2018/.

Hageman, Robert-Jan. "De Vlag Uit Als Steunbetuiging: Met Elkaar, Voor Elkaar!" Accessed June 25. https:// www.youtube.com/watch?v=NCXkAO8h6VU.

Ieven, Bram and Jan Overwijk. 2020. "We Created This Beast. The Political Ecology of COVID-19.” Eurozine. March 23. Accessed 25 July. https:// www.eurozine.com/we-created-this-beast/.

Javakaart. 2020. Personal Interview.

Kok, Auke. 2014. Domweg Ongelukkig in de Javastraat. Vrij Nederland. Accessed 2 July 2019.

Ladies' Circle 65 Bossche Parels. 2020. Homepage. Accessed June 25. https:// lc65.ladiescircle.nl/over-ons/.

Lefebvre, Henri. 1992/2004. Rhythmanalysis. Space, Time, and Everyday Life. London, New York: Continuum. https://monoskop.org/images/d/d2/ Lefebvre Henri Rhythmanalysis Space Time and Everyday Life.pdf.

Leigh, James. "Cultural Narratives of Crisis and COVID-19: Metaphors, (Un)Solidarity and Political Profiteering." Filmed 28 April 2020. Accessed June 25. https://youtu.be/aOLEJliMiXw.

Masuda, Jeffrey R., and Sonia Bookman. 2018. Neighbourhood Branding and the Right to the City. Progress in Human Geography. 42(2), 165-182.

Project Samen Sterk. 2020. Homepage. Accessed June 25. https://www.projectsamensterk.nl/.

Red Cross. 2020. Homepage. Accessed June 25. https://samensolidair.nl/.

Redactie Het Parool. 2010. Bewoners Indische Buurt nu wel Happy. Het Parool. Accessed 30 June 2019.

Rijssen-Holtens Nieuwsblad. 2020. "Actie Samen Solidair Tegen Corona." April 20. Accessed 25 June. https://www.rijssen-holtensnieuwsblad.nl/nieuws/ algemeen/970573/actie-samen-solidair-tegen-corona.

Sakizlioglu, Nur Bahar, and Loretta Lees. 2019. "Commercial Gentrification, Ethnicity, and Social Mixedness: The Case of Javastraat, Indische Buurt, Amsterdam." City \& Community. doi: 10.1111/cico.12451.

Sniečkute, Marija, and Gaižauskaitė, Inga. 2020. "Do You Trust Me, Premier? COVID-19 Pandemics in the Netherlands and Lithuania. A Remote Discussion on Trust in the Context of COVID-19." Social Sciences and Humanities Open. Accessed June 25, 2020. doi 10.2139/ssrn.3599771.

Summers, Brandi T. 2019. Black in Place: The Spatial Aesthetics of Race in a Post-Chocolate City. Chapel Hill: The University of North Carolina Press. UitegeestOnline.nl. 2020. "Hang De Vlag Uit; Met Elkaar Voor Elkaar!” April 2. Accessed June 25. https://www.uitgeestonline.nl/item/hang-de-vlag-uitmet-elkaar-voor-elkaar-3218/.

van Eck, Emil, Iris Hagemans, and Jan Rath. 2020. "The Ambiguity of Diversity: Management of Ethnic and Class Transitions in a Gentrifying Local 
Snieckute \& Fiore - Questioning COVID-19 Pre-packaged Solidarity

Shopping Street." Urban Studies 2020:1-16. doi:

10.1177/0042098019897008.

Vlagenclub. 2020. "Vlag Van Verbondheid.” Accessed 25 June. https://

www.vlaggenclub.nl/vlag-van-verbondenheid

Vostermans, Ron. 2020. "Tilburger Wil Nederland Verbinden Met Zijn Vlag: 'Laat Zien Dat We Samen Sterk Staan.” Omproep Braband, March 19.

Accessed 25 June, 2020. https://www.omroepbrabant.nl/nieuws/

3174089/tilburger-wil-nederland-verbinden-met-zijn-vlag-laat-zien-dat-

we-samen-sterk-staan.

Waldnet. 2020. Vlag 'Met Elkaar, Voor Elkaar!' Levert €37.500 Op.” Accessed 25

June. https://www.waldnet.nl/wn/nieuws/64715/

Vlag Met elkaar, voor elkaar levert \%E2\%82\%AC 37.500 op.html.

Zwarte Cross. 2020. "De Achterhoek Staat \#Samensterk!” Accessed June 25.

https://www.zwartecross.nl/samensterk/.

${ }^{1}$ Ladies' Circle 65 Bossche Parels is "an informal group of women up to 45 years old from 's-Hertogenbosch and its surroundings, with various professions and backgrounds" (Ladies' Circle 65 Bossche Parels 2020). It calls itself as a "service club", which carries out a lot of "beautiful projects locally, nationally and internationally" (ibid.). Among the concrete activities mentioned are collecting money, organizing high tea at women's shelter, walking with older people, etc.

2 Product unavailable at the end of June 2020

${ }^{3}$ Out of the fifty-six registered shops (about half of the one hundred and six shops present on the Javastraat), only three are pre-regeneration and immigrant-owned.

4 The street manager is a hybrid figure working in liaison between the organization of local entrepreneurs and the city government, whose role is to manage the commercial environment of a street to transform it in accordance to governmental directives and policy. 